\title{
The role of empowerment in improving internal process, customer satisfaction, learning and growth
}

\author{
Ziyad Saleh Al-Omari ${ }^{{ }^{*}}$, Khaled Abed Alqader Alomaria and Nader Mohammad Aljawarneh ${ }^{\mathrm{a}}$
}

${ }^{a}$ Business \& Human Resources Management, Jadara University, Jordan

\begin{tabular}{l}
\hline C H R O N I C L E \\
\hline Article history: \\
Received: September 42019 \\
Received in revised format: Sep- \\
tember 42019 \\
Accepted: October 12, 2019 \\
Available online: \\
October 12, 2019 \\
\hline Keywords: \\
Empowerment \\
Internal Process \\
Customer Satisfaction \\
Learn \& Growth \\
Safeway Company
\end{tabular}
A B S T R A C T

\begin{abstract}
The objective of this research was to identify the role of empowerment in enhancing Safeway Company's performance in Jordan using structural equation model (SEM). The authors used a predictive-descriptive strategy to determine Safeway Company's levels of empowerment. To evaluate the role of empowerment and performance, a questionnaire was designed and circulated. The data were examined using means, standard deviations, and multiple linear regression analyses. Empowerment and its dimensions from the Safeway company workers' viewpoint were ranked high in this survey. The performance level and its dimensions were also considered high from the Safeway company workers' perspective. Furthermore, the results suggest that both of the experienced groups showed significant differences regarding their empowerment's and performance perspective, meaning that employees with less than five years of job experience were more likely to perceive empowerment and performance, positively. In light of this result, the authors suggested the Safeway Company to increase and improve its performance to obtain customer satisfaction by encouraging employees to provide the company with feedback which improves the provided services to customers.
\end{abstract}

(C) 2020 by the authors; licensee Growing Science, Canada

\section{Introduction}

In the eighties of last century, the concept of empowerment arose in its present form, and contemporary administrative theories were dealt with due to its significance in administrative job development and its concrete result in attaining organizations' objectives and maximizing their performance (Danbom, 2007). The concept of empowerment has been mentioned in various schools of administration, without permission or allocation of the term currently being used (Faulkner \& Laschinger, 2008). As she was interested in the school of human and behavior relations, Mary P. Follett was the first to view the employment in human relations and some empowering literature as granting employees the right to participate in profit or gains and consideration of the needs of the employee as a human (Goetsch \& Davis, 2006). The behavioral theories of Hawthorn, Abraham Maslow's needs theory and the theories of $\mathrm{X}$ and $\mathrm{Y}$ have been concerned in the empowerment concept without concentrating on it as a term, by paying attention to satisfying the human needs of the employee during work (Kinicki \& Williams, 2006).The modern administrative schools have dealt with the concept of empowerment and have devoted a great deal of attention to the system theory which concerns organization and its aims in the light of the institution level, rather than looking at individuals, it has established the values of collaboration, coordination, and joint work through a cooperative team and skilled employees who can contribute actors, thereby enhancing the worker's interest with knowledge, ability and creativity (Kreitner et al., 2003). Safeway's administrative units face a number of issues arising from changes, developments, and transformations affecting their job in both the inner and external environment. Therefore, by restructuring themselves and engineering their job, they must observe these changes to maintain pace with the knowledge-based organizations model and embrace adopt leadership methods (Logan \& Ganster, 2007). The true issue at present is the abundance of information, knowledge and science, so it is very hard to handle these changes; hence why the concept of administrative empowerment and organizations, which

\footnotetext{
* Corresponding author.

E-mail address: naderaljawarneh@yahoo.com (Z. S. Al-Omari) 
encompasses contemporary leadership concepts that increase the performance of employees in the organization as it is necessary to raise their business efficiency and keep organizations within the competition provided by the department because of the application of this concept (Ogden, et al., 2006). Melhem (2006) points out the importance of empowerment but, among these issues, emphasizes that global governance in Western and Eastern world companies is still handled with caution, skepticism and other times, sometimes with management care and patronage. The purpose of this research is to contribute to the significance of this administrative concept and its significance in improving the job of contemporary organizations and effectively and effectively attaining their goals. The research, therefore, sought to address the following questions: What is the impact of empowerment on organizational performance? What is the impact of empowerment on internal processes? What is the impact of empowerment on learning and growth? and what is the impact of empowerment on customer satisfaction? The significance of this study is derived from the significance of organizational performance in empowerment. Furthermore, Serves Companies are one of Jordan's most significant business sectors. Empowerment plays a significant role in enhancing the company's performance; hence, this study investigates how empowerment can enhance performance. Finally, this research is aimed at filling the lack of literature on the effect of empowerment on retention of employees. This can be achieved by studying the following: Researchers' benefits in the findings of empowerment research. Explaining the active role of employees' retention support working on empowerment.

\section{Theory and Hypotheses}

\subsection{Empowerment, Internal Process, Customer Satisfaction\& Learning and Growth}

It has been observed in latest years that leadership science has concentrated its attention, to a large extent, on organizational development to prepare them and maintain their readiness to remain in competition under the rule of global international business leadership concept (Jing, 2015). The means of communications pay great attention to the human element, which is the basis of all procedures contributing to organizational success and their survival in the competition circle. Like most concepts related to human resources, the concept of administrative empowerment has been overshadowed, therefore, great attention and effort should be to human resources, as it is the most important empowerment concept (Ukil, 2016; Alomari, 2020). Empowerment is the independent variable of the study model, whereas organizational performance is the dependent variable.

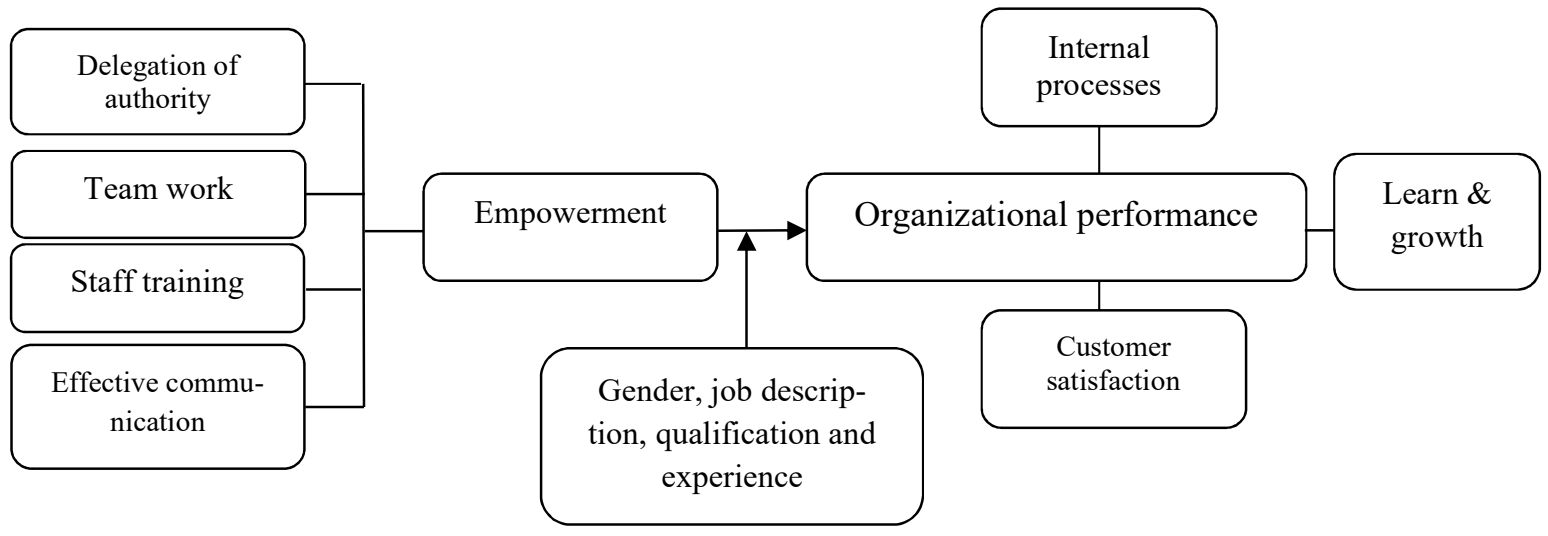

The concept of empowerment stems from the word power, which implies empowerment and empowerment as an administrative concept that aims to grant the employee the authority related to the job and subjects within his professional specialization and to release him through orders from the particular environments and to give him the freedom to take responsibility for his opinions, decisions and applications (Dambe \& Moorad, 2008). The organization's infrastructure is empowered and supported by providing technical resources, enhancing independence, self-responsibility, focusing on the organization's employees, providing them with the power, information, rewards and knowledge to protect them in the case of unexpected behaviour during consumer service, and focusing on employees who interact with the consumers (Zeglat et al., 2014). Ginnodo (1997) observed that empowerment, when managers and employees address issues traditionally limited to the research, emphasizes that the concept of empowerment refers to the intensification of attempts to strengthen the ties of collaboration, team spirit, self-confidence, innovation, independent thinking and entrepreneurial spirit among the employees of organisations, giving employees the freedom to operate at lower administrative levels closely linked to both functional experience and job description. Harvey (2001) argues that reducing administrative levels in sequence would help to apply the concept of empowerment to a large extent. This aims to reduce the reference, administrative sequence, flexibility, non-observance of these principles, reduce administrative levels and make the organizational structure more streamlined and more horizontal. Harnisch et al. (2013) pointed out that organizations of the 21 st century are becoming aware of the significance of moving from centralization to decentralization, which will empower employees' value and implies more liberal administration and involvement, which shall result in not only the employee is part of the organization, but he is also the organizations itself (Schermerhorn et al., 2002).It does not need to be monitored because it controls itself and the higher the amount of empowerment will lead to 
increase decentralization. The evolution of information systems and information technology will help today's managers transfer everything they can to devote to everything that is vital and important for the organization (Arogundade \& Arogundade, 2015).

The following can be recognized as the most significant empowerment elements:

Delegation of authority: Lawler (1994) identifies it as that authority given by the Chief Administrative Officer to one of his subordinates to practice some of the tasks of his office that he occupies. The commissioner shall be empowered to make decisions that he has authorized to take without reference to the president.

Teams: The team, according to Kinicki and Williams (2006) refers to as a group of individuals working together to achieve shared objectives.

Staff training: Training, as Dimitriades (2005) stated, is the process of providing training programs to train staff in decisionmaking skills, conflict management, problem-solving, communication skills and working with teams.

Effective Communication: Bagheri et al. (2011) points out that effective communication is the process of information transfer and exchange whereby concepts are unified, decisions are taken and implemented and the process of understanding and passing information from one person to another. Effective communication is a two-way communication that enables employees to express opinions and share ideas, and information. Organizational performance is a limited concept which measures the extent of achievement and represents organizational production as the primary supporters of the company performed by those organizations (Hsieh, 2006; Taamneh et al., 2018). In addition, organizational performance adds to the accessibility of financial resources and offers investment possibilities in various performance areas to help stakeholders and attain their goals (Ling \& Hung, 2010; Aljawarneh \& Atan, 2018; Alsaad et al., 2018). Performance, given its interactions with its inner and external environmental elements, is an embedded system of results of the organization's job. It involves individual performance in their organizational unit and measure the performance of organizational units within the organization's overall policy framework (Huang, 2014). Organizational performance results from both individual and organizational performance, social, economy, and culture. Organizations and businesses have been discovered to exchange some characteristics, qualifying them to lead institutions and become leaders in the industries in which they operate (Aljawarneh \& Atan, 2018). The characteristic feature of competence in these businesses is that they are capable of providing the best service. Consumer performance and capacity to innovate from moment to moment in the creation of fresh organizations, in order to respond to various modifications (Garrison, et al. 2010). Performance is defined by Hannabarger et al. (2007) as results reflecting the goals of the organization through employees' activities within the organization. The organizational output described by Brown and Laverich (2004) as "performing the job that enables the organization to reach its objectives and aims". Researchers vary in determining the areas in which performance is measured. The following are some of the views that researchers have addressed from a performance-card perspective to measure organizational performance as follows (Kaplan et al., 2001; Hannabarger, et al., 2007). Internal process: this is a concept focused on studies and literature since its importance for measuring the organization's ability to meet market requirements with the required date and standards. Maltz et al. (2003) identified operations as an indicator of the accessible manufacturing capacities and an indication of their operational performance and operated activities. Dimitriades (2005) referred to operations as the key to the success of an organization is its ability to measure its performance. The feedback from performance measurement provides management with the data necessary to determine the extent to which the organization meets its objectives, standards and the ability to improve and excel (Hannabarger, et al., 2007). Learning and growth: We assess the capacity of the organization to know and gain expertise in order to attain the social view that improves its skills and moves them to innovates (Khozein, 2012). Evaluation of people's experience and abilities, their creativity levels, the number of patents, and the absenteeism and turnover levels are the basis of evaluation in this dimension. The basis for success in this area is the system of incentives and promotions (Divandri \& Yousefi, 2011). Thus, the administration must give this system the utmost importance so that it can gain the loyalty of individuals and absorb resistance when taking remedial action for certain situations (Khozein, 2012). The focus is on organizational learning and growth that define and diagnose infrastructure, in which the company must build innovation and long-term development (Lesáková \& Dubcová, 2016). Customer satisfaction: With increasing competition between value-added service providers, every organization must be able to provide high-quality services to satisfy its customers and to ensure their loyalty to keep growing and competing. This market has experienced a fairly free and open competition and has become seriously threatened by potential new entrants (Kaplan et al., 2001; Aljawarneh \& Al-Omari, 2018). Considering the quality of the services, customers have more alternatives to choose as they see fit. They decide to choose in such a competitive market. This has forced the managements of organizations, including banks, to understand the customers' needs in order to achieve their satisfaction and to work towards their loyalty, which is an important factor to face competition as a result of modern trends that focus on customers rather than on the product (Hsieh, 2006; Al-Da'abseh et al., 2018; Voegtlin et al., 2015). Brown and Harvey (2001) acknowledged satisfaction as a rewarding feeling for the sacrifices the customer takes when buying. They (2011) also recognized customer satisfaction as an evaluation of the post-purchase or service-the outcome of its experience over time. The customer's satisfaction is to the extent that he or she believes that the product or service is equal to or exceeds its expectations. Customer satisfaction contributes to increasing the market share of any business organization by making the necessary adjustments to the product or service to be more responsive to the needs and expectations of the community members and the category they serve. The following hypotheses will guide the researcher in making presumptions and deep analysis.

$\mathbf{H}_{1}$ : The empowerment has a positive impact on organizational performance. 
H2: The empowerment has a positive impact on internal process.

H3: The empowerment has a positive impact on learn and growth.

H4: The empowerment has a positive impact on customer satisfaction.

H5: There is a significant difference of organizational performance for sample study evaluation level depending on demographic variables.

\section{Methodology}

This study can be classified as an exploratory and field study. It is considered exploratory because it attempts to explore the effect of the empowerment in organizational performance in Safeway Company. Moreover, field study because it is based on primary data collection from a questionnaire developed to identify the impact of empowerment on organizational performance. A quantitative approach has been used in this research in order to identify the role of empowerment in organizational performance. In addition, primary data are collected from the questionnaire. Consequently, after collecting and analyzing the data, the results have been discussed; the conclusion and recommendations can be reached. The study population consists of all employees in the Safeway Company in Jordan, (11 branches) (510 employees). The sample of the study has been a random sample of (260) employees. The analysis unit included: the administrative officer, accountant, marketing and human resources. This section describes the demographic statics and the suggested variables. As shown in Table 1 most of the responses are from male accounting for $90 \%$ of the sample. Most of the respondents also gold diploma or below holders (80\%) with 510 years of job experience (88\%). Most respondents almost are involved in marketing and accounting employees which account for $32 \%$ and $30 \%$ of the sample respectively.

Table 1

The descriptive statics of demographical variables

\begin{tabular}{|c|c|c|}
\hline demographical variables & Categories & Percent \\
\hline \multirow[t]{2}{*}{ Gender } & Male & 90.9 \\
\hline & female & 9.1 \\
\hline \multirow[t]{3}{*}{ Qualification level } & Diploma and below & 80.4 \\
\hline & Bachelor & 19.2 \\
\hline & Master & 0.4 \\
\hline \multirow[t]{3}{*}{ Experience } & Below 5 years & 2.6 \\
\hline & $>5$ and $<10$ & 88.3 \\
\hline & $>10$ and $<15$ & 9.1 \\
\hline \multirow[t]{7}{*}{ Job description } & Management & 12.1 \\
\hline & Inventory & 14.7 \\
\hline & Marketing & 32.1 \\
\hline & Accounting & 30.9 \\
\hline & Controlling & 7.5 \\
\hline & IT & 1.9 \\
\hline & Human resources & 0.8 \\
\hline
\end{tabular}

The factors included in the proposed framework are described in Table 2. As illustrated in the table, all empowerment dimensions are relatively high, with all average statistics between 3.8 and 4.2. The respondents also regarded their organizational performance as relatively high, with average statistics ranging between 3.9 and 41 for all performance dimensions.

Table 2

Variables descriptive statics

\begin{tabular}{lcccc}
\hline Variables & Mean & Std. Deviation & Variables & Mean \\
\hline Delegation of authority & 4.2528 & .63312 & Std. Dernal process & 3.9823 \\
Work team & 4.0818 & .68275 & Learn and Growth & 3.9317 \\
Staff Training & 4.0830 & .59421 & Customer satisfaction & 4.1245 \\
Effective Communication & 3.8849 & .65167 & & .49938 \\
\hline
\end{tabular}

Structure Equation Modeling used Partial Least Square (SEM-PLS) for testing hypotheses have been used. SEM-PLS can simultaneously examine the measurement model and the structural model (Gefen et al., 2011; Hair et al., 2011). This data analysis method is appropriate when the proposed framework is complex and includes multi-hierarchical constructs. It has also been widely used to deal with data structural problems such as skew distributions and omissions of regressors (Hair et al., 2011; Alsaad et al., 2018). We believe that this data analysis method is appropriate for this study because it is hard to claim that organizational performance is solely due to employees' empowerments. Moreover, we examine empowerment and performance at a hierarchical level which makes our framework quite complicated. However, using SEM for data analysis requires both an estimation model and design model evaluation. We predict both of them using SmartPLS2. We first estimate the reliability and validity of the measurement model. Cronbach's alphas and composite reliability are estimated to examine the reliability of the measurements. The results indicate, as shown in Table 3 below, that Cronbach's alphas for all items and 
composite reliability for all first-order buildings were within a limit of 0.70 , which confirmed the reliability of the first-order constructs model. The results show the measurement model's reliability. The mean Average Variance Extracted (AVE) and square roots of the AVE will also be evaluated to assess the converging and discriminated validity.

Table 3

AVE, Composite Reliability, Cronbach's alphas and Items loading

\begin{tabular}{|c|c|c|c|c|c|}
\hline Construct Name & AVE & Composite & Cronbach's alphas & Items name & Items loading \\
\hline \multirow{5}{*}{ Work teams } & \multirow{5}{*}{0.81} & \multirow{5}{*}{0.9627} & \multirow{5}{*}{0.9539} & Q10 & 0.8693 \\
\hline & & & & Q11 & 0.9209 \\
\hline & & & & Q12 & 0.92 \\
\hline & & & & Q13 & 0.887 \\
\hline & & & & Q14 & 0.9169 \\
\hline \multirow{9}{*}{ Staff training } & \multirow{6}{*}{0.74} & \multirow{6}{*}{0} & \multirow{6}{*}{0.9108} & Q15 & 0.8897 \\
\hline & & & & Q16 & 0.6983 \\
\hline & & & & Q17 & 0.8965 \\
\hline & & & & Q18 & 0.8899 \\
\hline & & & & Q19 & 0.9175 \\
\hline & & & & Q20 & 0.8867 \\
\hline & \multirow{4}{*}{0.80} & \multirow{4}{*}{0.9436} & \multirow{4}{*}{0.9203} & Q21 & 0.9116 \\
\hline & & & & Q22 & 0.9489 \\
\hline & & & & Q23 & 0.9245 \\
\hline Effective Communication & & & & Q24 & 0.8028 \\
\hline \multirow{5}{*}{ Delegation of authority } & \multirow{5}{*}{0.78} & \multirow{5}{*}{0.9454} & \multirow{5}{*}{0.9265} & Q5 & 0.7461 \\
\hline & & & & Q6 & 0.9359 \\
\hline & & & & Q7 & 0.9382 \\
\hline & & & & Q8 & 0.9125 \\
\hline & & & & Q9 & 0.8607 \\
\hline \multirow{10}{*}{ Internal processes } & \multirow{10}{*}{0.5} & \multirow{10}{*}{0.9066} & \multirow{10}{*}{0.887} & Q25 & $0.5812 *$ \\
\hline & & & & Q26 & 0.6406 \\
\hline & & & & Q27 & 0.6287 \\
\hline & & & & Q28 & 0.6229 \\
\hline & & & & Q29 & 0.7998 \\
\hline & & & & Q30 & 0.7752 \\
\hline & & & & Q31 & 0.7444 \\
\hline & & & & Q32 & 0.7096 \\
\hline & & & & Q33 & 0.7476 \\
\hline & & & & Q34 & 0.7493 \\
\hline \multirow{8}{*}{ Growth } & \multirow{8}{*}{0.5662} & \multirow{8}{*}{0.9118} & \multirow{8}{*}{0.8883} & Q35 & 0.6948 \\
\hline & & & & Q36 & 0.8176 \\
\hline & & & & Q37 & 0.7991 \\
\hline & & & & Q38 & 0.8252 \\
\hline & & & & Q39 & 0.7954 \\
\hline & & & & Q40 & 0.768 \\
\hline & & & & Q41 & 0.6794 \\
\hline & & & & Q42 & 0.612 \\
\hline \multirow{5}{*}{ Customer Satisfaction } & & & & Q43 & 0.7776 \\
\hline & & & & Q44 & 0.9228 \\
\hline & 0.73 & 0.93 & 0.90 & Q45 & 0.8881 \\
\hline & & & & Q46 & 0.9243 \\
\hline & & & & Q47 & 0.7552 \\
\hline
\end{tabular}

Items in bold have been deleted

The results in Table 3 show that the AVEs were above the conventional value of 0.5 for all structures, which confirmed the convergent validity of the measurement model. To estimate the validity of the discrimination, the square roots of the AVEs for all first-order constructs were calculated and presented in Table 4. The findings indicate that the AVE square roots are all greater than inner construction correlations, which demonstrate discriminate validity. In general, the statistics shown above indicate that our measurement model is sufficiently reliable and valid, as shown in section 2 and 3 . In order to verify the suggested hypotheses, we have estimated the structure model using PLS bootstrapping procedures.

\section{Table 4}

The AVEs square roots

\begin{tabular}{lcccccccc}
\hline variable name & AVE & 1 & 2 & 3 & 4 & 5 \\
\hline Delegation of authority (1) & 0.78 & 1 & & & & & \\
Work team (2) & 0.81 & 0.76 & 1 & & & \\
Staff Training (3) & 0.74 & 0.29 & 0.35 & 1 & & \\
Effective Communication (4) & 0.8 & 0.26 & 0.31 & 0.67 & 1 & \\
Internal processes (5) & 0.5 & 0.31 & 0.39 & 0.47 & 0.47 & \\
Learn and Growth (6) & 0.56 & 0.34 & 0.4 & 0.42 & 0.38 & 0.49 \\
Customer satisfaction (7) & 0.73 & 0.31 & 0.37 & 0.43 & 0.34 & 0.4 & 0.39 \\
\hline
\end{tabular}


As shown in Table 5, the coefficient of paths is strong and significant as shown in Table 5 (ratio of the route $=069, \mathrm{p}=0.000$ ), which indicates that organizational empowerment is improved as well as organizational performance, and by that, the main hypothesis is confirmed. With respect to the sub-hypotheses, the results indicate that empowerment significantly influences the internal processes (Path coefficient $=0.60, \mathrm{p}=0.000$ ), which supports H1a. Similarly, empowerment also has significant influences on learning and growth (Path coefficient $=0.60, p=0.000$ ), supporting H1b. Finally, our regression analysis confirms that the path coefficients between empowerment and customer satisfaction is significant $($ Path coefficient $=0.48, p=$ $0.000)$, supporting H1c.

\section{Table 5}

The result of PLS regression using bootstrapping procedures

\begin{tabular}{|c|c|c|c|c|c|}
\hline Path specification & Path coefficients & Standard Deviation & Standard Error & T Statistics & $\mathrm{P}$ value \\
\hline Empowerment $\rightarrow$ Customer Satisfaction & 0.48 & 0.07 & 0.07 & 6.11 & 0.000 \\
\hline Empowerment $\rightarrow$ Learning \& Growth & 0.50 & 0.07 & 0.07 & 6.68 & 0.000 \\
\hline Empowerment $\rightarrow$ Internal processes & 0.60 & 0.05 & 0.05 & 10.15 & 0.000 \\
\hline Empowerment $\rightarrow$ Overall Performance & 0.69 & 0.05 & 0.05 & 12.69 & 0.000 \\
\hline
\end{tabular}

In order to examine the variations in sample perception, we have carried out t-test and ANOVA analysis, both with regard to empowerment and organizational performance according to the demographic characteristics. In the meantime, ANOVA analysis will be applied to examine the differences according to the job description, qualification, and experience. The results of the t-test are shown in Table 6 for both empowerment and performance according to gender. The outcome shows that the perceptions of empowerment and performance in gender categories are not significantly different.

Table 6

Independent Samples t Test according to gender

\begin{tabular}{|c|c|c|c|c|c|c|}
\hline & & $\mathrm{F}$ & Sig. & $\mathrm{t}$ & Df & Sig. (2-tailed) \\
\hline \multirow[t]{2}{*}{ Performance } & Equal variances assumed & 3.086 & .080 & .470 & 267 & .639 \\
\hline & Equal variances not assumed & & & .381 & 27.010 & .706 \\
\hline \multirow[t]{2}{*}{ Empowerment } & Equal variances assumed & 1.707 & .192 & 1.037 & 267 & .301 \\
\hline & Equal variances not assumed & & & .906 & 27.647 & .373 \\
\hline
\end{tabular}

Table 7 shows the result of ANOVA analysis for both empowerment and performance according to the job description, qualification, and experience. The results indicate that there are significant differences between groups with different levels of experience regarding both empowerment and performance. Moreover, the results show that there are significant differences between groups with different qualifications only regarding empowerment. Finally, the results reveal that there are no differences between groups with different job titles regarding both empowerment and performance.

Table 7

The results of ANOVA test

\begin{tabular}{|c|c|c|c|c|c|c|c|}
\hline Variable name & \multicolumn{2}{|c|}{ Dependent variable } & Sum of Squares & $\mathrm{df}$ & Mean Square & $\mathrm{F}$ & Sig. \\
\hline \multirow{6}{*}{$\begin{array}{l}\text { Differences } \\
\text { according to } \\
\text { experience }\end{array}$} & \multirow[t]{3}{*}{ Performance } & Between Groups & 2.276 & 2 & 1.138 & 6.179 & .002 \\
\hline & & Within Groups & 48.996 & 266 & .184 & & \\
\hline & & Total & 51.272 & 268 & & & \\
\hline & \multirow[t]{3}{*}{ Empowerment } & Between Groups & 2.736 & 2 & 1.368 & 5.720 & .004 \\
\hline & & Within Groups & 63.615 & 266 & .239 & & \\
\hline & & Total & 66.351 & 268 & & & \\
\hline \multirow{6}{*}{$\begin{array}{l}\text { Differences } \\
\text { according to } \\
\text { qualification }\end{array}$} & \multirow[t]{3}{*}{ Performance } & Between Groups & .498 & 3 & .166 & .867 & .459 \\
\hline & & Within Groups & 50.774 & 265 & .192 & & \\
\hline & & Total & 51.272 & 268 & & & \\
\hline & \multirow[t]{3}{*}{ Empowerment } & Between Groups & 5.365 & 3 & 1.788 & 7.771 & .000 \\
\hline & & Within Groups & 60.985 & 265 & .230 & & \\
\hline & & Total & 66.351 & 268 & & & \\
\hline \multirow{6}{*}{$\begin{array}{l}\text { Differences } \\
\text { according to } \\
\text { Job descrip- } \\
\text { tion }\end{array}$} & \multirow[t]{3}{*}{ Performance } & Between Groups & 2.287 & 7 & .327 & 1.741 & .100 \\
\hline & & Within Groups & 48.985 & 261 & .188 & & \\
\hline & & Total & 51.272 & 268 & & & \\
\hline & \multirow[t]{3}{*}{ Empowerment } & Between Groups & 2.330 & 7 & .333 & 1.357 & .224 \\
\hline & & Within Groups & 64.021 & 261 & .245 & & \\
\hline & & Total & 66.351 & 268 & & & \\
\hline
\end{tabular}

In order to get a closer look at the difference between groups regarding both empowerment and performance, we ran Scheffe post hock analysis. Differences according to experience and qualification were examined because the ANOVA analysis showed that the level of empowerment and performance was different according to experience and qualification. Results of Scheffe post hock analysis according to qualification level are shown in Table 8. The results indicate that the perception of empowerment varies among diploma or below, master and bachelor holders. Both the "diploma or below" and bachelor holders view empowerment practices in their organization more positively compared with the perception of the people with masters' degree of science. We also tried to run Scheffe post hock analysis according to experience for both empowerment and performance. But, the descriptive statistics as shown in Table 10 indicate that all responses are from three experience categories: "below 5 years", "more than 5 and less than 10", and "more than 10 and less than 15". For the last category, we 
had only one observation which is insufficient to run the Scheffe post hock analysis. As we have only sufficient observation for the first two experience categories, we ran t-test instated as it is the appropriate method to compare between two groups.

Table 8

Scheffe analysis according to qualification level

\begin{tabular}{|c|c|c|c|c|c|}
\hline Dependent Variable & (I) qualification level & (J) qualification level & Mean Difference (I-J) & $\begin{array}{l}\text { Std. } \\
\text { Error }\end{array}$ & Sig. \\
\hline \multirow[t]{6}{*}{ Performance } & Diploma and below & Bachelor & -.02888 & .16845 & .985 \\
\hline & & Master & .10500 & .18864 & .857 \\
\hline & Bachelor & Diploma and below & .02888 & .16845 & .985 \\
\hline & & Master & .13388 & .09412 & .365 \\
\hline & Master & Diploma and below & -.10500 & .18864 & .857 \\
\hline & & Bachelor & -.13388 & .09412 & .365 \\
\hline \multirow[t]{6}{*}{ Empowerment } & Diploma and below & Bachelor & .23394 & .18219 & .440 \\
\hline & & Master & $.64343^{*}$ & .20403 & .008 \\
\hline & Bachelor & Diploma and below & -.23394 & .18219 & .440 \\
\hline & & Master & $.40949^{*}$ & .10180 & .000 \\
\hline & Master & Diploma and below & $-.64343^{*}$ & .20403 & .008 \\
\hline & & Bachelor & $-.40949^{*}$ & .10180 & .000 \\
\hline
\end{tabular}

*. The mean difference is significant at the 0.05 level.

Table 9

Independent Samples t-Test according to experiences

\begin{tabular}{|c|c|c|c|c|c|c|c|}
\hline & & $\mathrm{F}$ & Sig. & $\mathrm{T}$ & df & Sig. (2-tailed) & Mean Difference \\
\hline \multirow[t]{2}{*}{ Performance } & Equal variances assumed & 18.835 & .000 & 3.359 & 262 & .001 & .22588 \\
\hline & Equal variances not assumed & & & 2.479 & 58.715 & .016 & .22588 \\
\hline \multirow[t]{2}{*}{ Empowerment } & Equal variances assumed & 17.398 & .000 & 2.907 & 262 & .004 & .21770 \\
\hline & Equal variances not assumed & & & 2.205 & 59.698 & .031 & .21770 \\
\hline
\end{tabular}

Table 9 shows the results of t-test which indicate that there is a significant difference between the two experience groups in their perception of both empowerment and performance.

Table 10

The mean of performance and empowerment according to experiences

\begin{tabular}{clccc}
\hline Dependent variables & Experience & Mean & Std. Deviation & Std. Error Mean \\
\hline Performance & below 5 years & 4.0554 & .37130 & .62480 \\
& more than 5 and less than 10 & 3.8296 & .02544 & .08749 \\
\hline Empowerment & below 5 years & 4.1142 & .42191 & .02891 \\
& more than 5 and less than 10 & 3.8965 & .09438 & .67401 \\
\hline
\end{tabular}

Mean statistics shown in Table 10 shows that the employees with less than 5 years of experiences are more likely to perceive empowerment and performance positively.

\section{Findings and conclusion}

The research was driven by the need to help us understand the impact of empowerment on performance through employees. It has explored the impact of empowerment on overall performance, internal processes, learning and growth, as well as customer satisfaction. Results have concluded that there was a positive effect for the empowerment in achieving the overall performance and achieving customer satisfaction. Moreover, on the basis of the current study and prior studies mentioned in the literature, the researchers have proposed that in view of the results it seems necessary for other companies to use empowerment with all their applications on all sections of companies. In addition, Safeway management should ensure about the operational performance. It is also necessary that management of Safeway provide different services for customers, and learn and benefit from the previous experiences.

\section{References}

Aljawarneh, N. M. S., \& Atan, T. (2018). Linking tolerance to workplace incivility, service innovation, knowledge hiding, and job search behavior: The mediating role of employee cynicism. Negotiation and Conflict Management Research, 11(4), 298-320.

Aljawarneh, N., \& Al-Omari, Z. (2018). The role of enterprise resource planning systems ERP in improving customer relationship management CRM: An empirical study of safeway company of Jordan. International Journal of Business and Management, 13(8), 86-100.

Alomari, Z. (2020). Does human capital moderate the relationship between strategic thinking and strategic human resource management?. Management Science Letters, 10(3), 565-574.

Alsaad, A., Mohamad, R., Taamneh, A., \& Ismail, N. A. (2018). What drives global B2B e-commerce usage: an analysis of the effect of the complexity of trading system and competition pressure. Technology Analysis \& Strategic Management, 30(8), 980-992.

Arogundade, O. T., \& Arogundade, A. B. (2015). Psychological empowerment in the workplace: Implications for employees' career satisfaction. North American Journal of Psychology, 17(1), 27.

Bagheri, G., Matin, H. Z., \& Amighi, F. (2011). The relationship between empowerment and organizational citizenship behavior of the pedagogical organization employees. Iranian Journal of Management Studies, 4(2), 53. 
Dambe, M., \& Moorad, F. (2008). From power to empowerment: A paradigm shift in leadership. South African Journal of Higher Education, 22(3), 575-587.

Danbom, D. (2007). Equal Opportunity Empowerment. Business Performance Management.

Dimitriades, Z. S. (2005). Employee empowerment in the Greek context. International journal of manpower, 26(1), 80-92.

Divandri, A., \& Yousefi, H. (2011). Balanced scorecard: A tool for measuring competitive advantage of ports with focus on container terminals. International Journal of Trade, Economics and Finance, 2(6), 472-477.

Elrehail, H., Emeagwali, O. L., Alsaad, A., \& Alzghoul, A. (2018). The impact of transformational and authentic leadership on innovation in higher education: the contingent role of knowledge sharing. Telematics and Informatics, 35(1), 55-67.

Faulkner, J., \& Laschinger, H. (2008). The effects of structural and psychological empowerment on perceived respect in acute care nurses. Journal of nursing management, 16(2), 214-221.

Garrison, R. H., Noreen, E. W., Brewer, P. C., and McGowan, A (2010). Managerial accounting, Issues in Accounting Education, 25(4), $792-793$.

Gefen, D., Rigdon, E. E., \& Straub, D. (2011). Editor's comments: an update and extension to SEM guidelines for administrative and social science research. Mis Quarterly, 35(2), 3-14.

Ginnodo, B. (Ed.). (1997). the power of empowerment: What the experts say and 16 actionable case studies. Bill Ginnodo.

Goetsch, D. L., \& Davis, S. (2006). Quality management: Introduction to total quality management for production, processing, and services. Prentice Hall.

Hair, J. F., Ringle, C. M., \& Sarstedt, M. (2011). PLS-SEM: Indeed a silver bullet. Journal of Marketing theory and Practice, 19(2), 139152.

Hannabarger, C., Buchman, F., \& Economy, P. (2011). Balanced scorecard strategy for dummies. John Wiley \& Sons.

Harnisch, D. L., Guetterman, T. C., Samofalova, O., \& Kussis, Y. (2013). Progressive Educational Actions in a Post-Soviet Republic: Meaningful Collaborations and Empowerment. International Journal of Progressive Education, 9(2).

Brown, D., \& Harvey, D. (2001). An experiential approach to organization development 7 th edition.

Hsieh, H.C. (2006). A research on the relations among organizational change recognition organizational commitment and work performance - take Hsing chung paper company as an example. Taiwan: Master's degree thesis, Graduate Studies of Management.

Huang, C. L. (2014). The effects of knowledge management on organizational performance of Taiwan listed communication network companies: Using cloud technology investment as the moderator. Journal of Global Business Management, 10(2), 117.

Jain, S., \& Jain, R. (2014). Employee Empowerment in Indian Banks: An Empirical Study. Journal of Institute of Public Enterprise, 37.

Jing, Y. (2015). Between control and empowerment: governmental strategies towards the development of the non-profit sector in China. Asian Studies Review, 39(4), 589-608.

Kaplan, R. S., Davenport, T. H., Robert, N. P. D. K. S., Kaplan, R. S., \& Norton, D. P. (2001). The strategy-focused organization: How balanced scorecard companies thrive in the new business environment. Harvard Business Press.

Khairo Al-Da'abseh, T., Saleh Aljawarneh, N. M., \& Mustafa Shwiyat, Z. (2018). Marketing Mix Startegies and Its Impact on Organizational Performance Efficiency in The Jordanian Company for Investment and Supply-Safeway: An Empirical Study. Nader Mohammed and Mustafa Shwiyat, Ziyad, Marketing Mix Startegies and Its Impact on Organizational Performance Efficiency in The Jordanian Company for Investment and Supply-Safeway: An Empirical Study (February 6, 2018).

Khozein, A. (2012). Balanced Scorecard Should is Attention More in Organizations. International Journal of Research in Management, 2 (1), 38-46.

Kinicki, A., \& Williams, B. (2006). Management: A Practical Instruction. Mc Grew Hill, Irwin.

Kreitner, R. \& Kinichia,A.,\& Cole, N. (2003).Fundamentals of Organizational Behavior. Higher Education, Mc Grew Hill, Canada.

Lawler III, E. E. (1994). Total quality management and employee involvement: are they compatible? Academy of Management Perspectives, 8(1), 68-76.

Lesáková, L., \& Dubcová, K. (2016). Knowledge and use of the balanced scorecard method in the businesses in the Slovak Republic. Procedia-Social and Behavioral Sciences, 230, 39-48.

Ling, Y. H., \& Hung, L. (2010). The influence of intellectual capital on organizational performance: The mediation effect of intellectual capital management strategy. Human Resource Management Student Newspaper, 10(1), 1-27.

Logan, M. S., \& Ganster, D. C. (2007). The effects of empowerment on attitudes and performance: The role of social support and empowerment beliefs. Journal of Management Studies, 44(8), 1523-1550.

Maltz, A. C., Shenhar, A. J., \& Reilly, R. R. (2003). Beyond the balanced scorecard:: Refining the search for organizational success measures. Long Range Planning, 36(2), 187-204.

Melhem, Y. (2006). Empowerment as a contemporary administrative concept. Cairo: Arab Organization for Administrative Development.

Ogden, S., Glaister, W. \& Marginson, D. (2006). Empowerment and accountability: Evidence from the privatized water industry. Journal of Management Studies, 433, 521- 555.

Schermerhorn, J., Hunt, J., Obson, R. (2000). Organizational Behavior. McGraw - Hill, New York.

Taamneh, A., Alsaad, A. K., \& Elrehail, H. (2018). HRM practices and the multifaceted nature of organization performance: The mediation effect of organizational citizenship behavior. EuroMed Journal of Business, 13(3), 315-334.

Voegtlin, C., Boehm, S. A., \& Bruch, H. (2015). How to empower employees: using training to enhance work units' collective empowerment. International Journal of Manpower, 36(3), 354-373.

Ukil, M. I. (2016). The impact of employee empowerment on employee satisfaction and service quality: empirical evidence from financial enterprizes in Bangladesh. Business: Theory and Practice, 17, 178.

Zeglat, D., Aljaber, M., \& Alrawabdeh, W. (2014). Understating the impact of employee empowerment on customer-oriented behavior. Journal of Business Studies Quarterly, 6(1), 55.

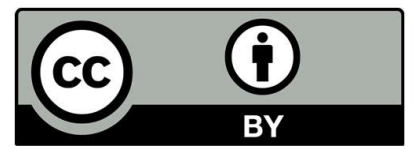

(C) 2020 by the authors; licensee Growing Science, Canada. This is an open access article distributed under the terms and conditions of the Creative Commons Attribution (CC-BY) license (http://creativecommons.org/licenses/by/4.0/). 